\title{
INTRODUCTION TO THE SPECIAL ISSUE ON "HIGHER EDUCATION IN AFRICA: GLOBAL PERSPECTIVES”
}

\author{
Josiah Zachary Nyangau ${ }^{1}$ \\ Louisiana State University, USA
}

The global higher education space continues to experience a period of widespread reform and transformation and while there are multiple and varied contextual drivers of change, globalization is generally viewed as the one fundamental force underlying much of the upheaval (Altbach \& Knight, 2007; Altbach, Reisberg, \& Rumbley, 2009). Globalization is a complex and multidimensional phenomenon whose effects manifest themselves in higher education in a variety of ways, thus making it impossible to assess its precise impact. That notwithstanding, relevant studies identify broad twenty-first century trends worth noting including the development of mass higher education systems, the widespread use of technology for teaching and learning, the emergence of a global marketplace for higher education, a growing convergence in higher education policymaking, and the emergence of international accreditation regimes (Altbach \& Knight, 2007; Altbach, Reisberg, \& Rumbley, 2009; Douglass, King, \& Feller, 2009; Trow, 2000).

Moreover, the classification of education as a tradable service under the General Agreement on Trade in Services (GATS) framework liberalized trade in educational services and sparked profound structural changes in the global landscape for higher education (Altbach \& Knight, 2007; Knight, 2011). Specifically, it furnished programs and providers enhanced access to education markets particularly in developing countries and thus created new opportunities for cross-border mobility and the concomitant competition (Altbach \& Knight, 2007; Knight, 2011). All told, perhaps the single most dominant manifestation of globalization in higher education today is the dramatically altered landscape in which the sector operates, one that is underscored by a steady drumbeat of competition and disruption.

There has been a broad range of responses to the pressures of globalization throughout the higher education ecosystem, ranging from national to regional and even supranational. Across Europe, the Bologna Process, launched following the Bologna Declaration, represents an ambitious transnational effort to harmonize the architecture of systems of higher education among signatory countries to improve the compatibility of degree structures (Adelman, 2008; Gaston, 2010; Wende, 2000; 2009). The ensuing reforms

\footnotetext{
${ }^{1}$ Correspondence: Josiah Nyangau, Assistant Director, Office of Institutional Effectiveness, Louisiana State University, 336 Thomas Boyd Hall, Baton Rouge, LA 70803, USA; Email: jnyangau@kent.edu
} 
focused on several priorities designed to culminate in the establishment of a globally competitive pan-European Higher Education Space (Adelman, 2008; Gaston, 2010; van der Wende, 2000; 2009). Perhaps the one most noteworthy outcome of the Bologna reforms is the construction of the Qualifications Framework in the European Higher Education Area, a meta-framework to which allied countries key their national-level qualifications frameworks (Adelman, 2008; Bergan \& Deca, 2018; Gaston, 2010). This meta-framework is intended to facilitate the mutual recognition of qualifications and thus foster greater student mobility and graduate employability in signatory countries. Overall, while implementation of Bologna Process reforms has been unsystematic and structural challenges remain, much progress has been achieved toward improved readability and comparability of degrees (Bergan \& Deca, 2018; Curaj, Deca, \& Pricopie, 2018; Gaston, 2010).

The Tuning Project, closely linked to the Bologna Process, also originated with Europe, and its fundamental focus is on the reform of educational structures - at the subject area level - to increase transparency regarding program learning outcomes (Adelman, 2008; Gaston, 2010; Hahn \& Teferra, 2013). Specifically, Tuning is a collaborative and inclusive process that brings together faculty by discipline and draws upon perspectives from pertinent stakeholders including employers and professional associations to identify and define discipline-specific frameworks of learning outcomes for students at each degree level (Adelman, 2008; Gaston, 2010; Hahn \& Teferra, 2013). That is, the process addresses what students are expected to know and be able to do upon completion of a degree program for a specific discipline (Adelman, 2008; Gaston, 2010). Tuning thus fosters the development of an integrated curriculum in individual disciplines (Adelman, 2008; Gaston, 2010; Hahn \& Teferra, 2013), which helps facilitate greater mobility of students throughout the European Higher Education Space (Adelman, 2008; Gaston, 2010).

Broadly speaking, the Bologna Process inspired a global movement of disparate, multifarious efforts toward policy reforms in higher education (Knight, 2012). In the United States, the American Historical Association and a few Midwestern states were the first to adopt Tuning initiatives, even though the overall response has been relatively modest (McInerney, 2017). Perhaps most noteworthy of all is that the "Dublin Descriptors" (generic statements that describe expected qualifications or outcomes associated with completion of each Bologna degree cycle) and the subsequent Qualifications Framework in the European Higher Education Area (Adelman, 2008) informed the development of the Degree Qualifications Profile (DQP). The DQP is a framework that defines generic learning outcomes for students at three different degree levels -- the associate's level, the bachelor's level, and the master's level -- regardless of field of study (Lumina Foundation, 2014).

Further afield, higher education across Africa continues to experience the ripple effects of the Bologna Process as evidenced by incremental and piecemeal reforms and policy initiatives to foster integration and harmonization (Hahn \& Teferra, 2013; Knight, 2012, 2013; Woldegiyorgis, 2018) with the goal of establishing a Pan-African Higher Education Space analogous to the European Higher Education Area (Oanda, 2013; Woldegiyorgis, 2018). In that regard, Tuning Africa has received the public endorsement of prominent actors in higher education at different policy levels, most notably the African Union (Hahn \& Teferra, 2013; Woldegiyorgis, 2018). In principle, the prospects of structural reforms to achieve greater integration and harmonization of higher education systems in Africa hold much promise; in reality, however, the pace of change remains glacial and intractable challenges lie ahead as some of the policy initiatives and reforms may be in tension with national or even regional priorities. 
The theme of this Special Issue of the Forum for International Research in Education is "Higher Education in Africa: Global Perspectives," and its goal was to provide an opportunity for researchers and practitioners to engage the broad range of topics that transcend national borders. Submissions were invited to examine such topics as outcomes analyses for international organizations in African higher education; the influence of Bologna and the European Standards and Guidelines for Quality Assurance on globalized standards for African higher education institutions; isomorphism versus institutional diversification in African higher education; internationalization initiatives within the African continent; the influence of colonial institutions on African universities' approaches to internationalization; and educational policy borrowing in African higher education. The special issue attracted several submissions from different countries and from a wide variety of disciplines, a reflection of the interdisciplinary nature of the field of comparative and international education. Taken together, these articles advance our knowledge regarding the influences of globalization and internationalization on higher education in Africa and the concomitant policy responses.

In the first article, "Motivations of faculty engagement in internationalization: An agenda for future research," I explore drivers of faculty involvement in internationalization activities in the context of higher education in the United States, especially where this work is not recognized and rewarded in tenure and promotion decisions. I then cast a focus on patterns of faculty engagement in internationalization in Africa, particularly the importance of international partnerships and exchange programs to conceptualizing faculty activities with international dimensions. Yeukai Mlambo and Aryn Baxter further discuss linkages and collaborations between universities in "What can I offer America? A critical analysis of faculty motivations and perceptions in North-South university partnerships." The authors problematize international partnerships, examine the potential benefits that accrue to participating faculty, and discuss the inequalities inherent in North-South collaborations.

Ibrahim Ogachi and James Matiang'i, in their article, "The East African higher education area: A global or regional higher education space?” argue that the Bologna Process provided renewed momentum for longstanding efforts to create a qualifications framework for higher education within the East African Community. The authors examine the multiplicity of actors and highlight some of the structural challenges to the realization of the East African Community Higher Education Area. In "Educational policy borrowing in the Cameroonian higher education system: A debatable paradigm from stakeholders' perspectives," Elizabeth Eta and Joyce Vuban discuss the varied perceptions of the multiple actors in educational policy borrowing, and the influence of the Bologna principles on educational policy in Cameroon. Further, in "Indirect coercive transfer and educational copying under dictatorship: The case of Tunisia," Tavis Jules and Donia Bouhlila explore the complexities of wholesale importation of policies without thoughtful consideration of important contextual circumstances. And Pascal Ramdé, Pierre Lapointe, and Martial Dembélé discuss Bologna-inspired reforms in "The appropriation of policy changes in higher education by students in sub-Saharan Africa: The case of the Bachelor-Master-Doctorate reform in Burkina Faso." The authors found that students had limited knowledge about the reforms implemented, perhaps an indication of the limited role that this group of stakeholders plays in the politics of education policy borrowing.

In "The ontology of mention: Contexts, contests and constructs of academic identity among University of Zambia faculty," Ferdinand Chipindi and Frances Vavrus examine the effects of neoliberal policies on higher education in Zambia. The authors focus on the emphasis that these reforms place on research and publications and highlight the increasingly 
familiar challenge of lack of funding that faculty face in relation to their scholarship. Along similar lines, Nelson Nkhoma's "Producing relevant medical education through communityengaged scholarship" looks at the issue of multiple epistemologies as it relates to the production and dissemination of medical education in Malawi. The author argues that Malawian faculty infuse pertinent local epistemologies into their scholarship.

In "Rebuilding tertiary education in Guinea-Bissau: Can it be done?” Brandon Lundy examines some of the challenges facing post-secondary education in that west African nation. The author discusses experiences of other similarly situated countries and concludes with localized recommendations. The George Odhiambo article "The role of Kenyan universities in national development" postulates about the importance of higher education in supporting economic growth and social transformation. The author suggests that university education in Kenya faces intractable challenges, perhaps none more pressing than funding and quality. And Sintayehu Alemu revisits the history surrounding the evolution of and conceptions about higher education in "Brief history, meaning, and idea of university." The author contends that forms of higher learning existed in Africa and elsewhere before the arrival of colonial rule.

Finally, the special issue guest editor and the journal editors would like to thank all authors for their valuable contributions which expand our understanding of the broad range of topics pertaining to the landscape of higher education in Africa and enrich our field. We also thank the peer-reviewers for providing constructive criticisms to improve these manuscripts. We believe that the journal's readership will find these contributions meaningful and thought-provoking. More importantly, we hope these contributions spur new ideas for further research.

\section{Acknowledgements}

I would like to thank Dr. Martha Merrill for providing feedback on an earlier version of this introduction.

\section{About the Author \\ Josiah Z. Nyangau, PhD, currently serves as assistant director of assessment in the Office of Institutional Effectiveness at Louisiana State University. He previously served as program coordinator for Accreditation, Assessment and Learning at Kent State University, where he also taught in the Higher Education Administration program. He earned his bachelor's degree in Education from Kenyatta University, master's degree in Geography from Ohio University, and PhD in Higher Education Administration from Kent State University. His research addresses issues related to the influences of globalization on higher and postsecondary education, especially the internationalization of higher education, curriculum in higher education, education policy learning and borrowing, international partnerships, and accreditation or quality assurance for higher education. His research also explores assessment for learning in higher education as well as academic reward systems and faculty work lives.}

\section{References}

Adelman, C. (2008). The Bologna club: What U.S. higher education can learn from a decade of European reconstruction. Washington, DC: Institute for Higher Education Policy.

Altbach, P., \& Knight, J. (2007). Internationalization of higher education: Motivations and realities. Journal of Studies in International Education, 11, 290-305. 
Altbach, P. G., Reisberg, L., \& Rumbley, L. E. (2009). Trends in global higher education: Tracking an academic revolution. Report prepared for UNESCO 2009 World Conference on Higher Education. Paris: UNESCO.

Bergan, S. \& Deca, L. (2018). Twenty years of Bologna and a decade of EHEA: What is next? In A. Curaj, L. Deca \& R. Pricopie (Eds.), European higher education area: The impact of past and future policies (pp. 295-319). Cham, Switzerland: Springer.

Curaj, A., Deca, L. \& Pricopie, R. (2018). Twenty years of Bologna and a decade of EHEA: What is next? In A. Curaj, L. Deca \& R. Pricopie (Eds.), European higher education area: The impact of past and future policies (pp. 1-11). Cham, Switzerland: Springer.

Douglass, J., A, King, C., J., Feller, I. (2009). A room with a view: Globalization, universities, and the imperative of a broader U.S. perspective. In J. A. Douglass, C. J. King, \& I. Feller (Eds.), Globalization's muse: Universities and higher education in a changing world (pp. 1-11). Berkley, CA: Public Policy Press / Center for Studies in Higher Education.

Gaston, P. L. (2010). The Challenge of Bologna: What United States has to learn from Europe, and why it matters that we learn it. Sterling, VA: Stylus Publishing.

Hahn, K. \& Teferra, D. (2013). Tuning as an instrument of systematic higher education reform and quality enhancement: The African Experience. Tuning Journal for Higher Education 1(1), 127-163.

Knight, J. (2011). Higher education crossing borders: A framework and overview of new developments and issues. In R. Sakamoto \& D. W. Chapman (Eds.), Cross-border partnerships in higher education: Strategies and issues (16-41). New York, NY: Routledge.

Knight, J. (2012). A Conceptual Framework for the Regionalization of Higher Education: Application to Asia. In J. N. Hawkins, K. H. Mok, and D. E. Neubauer (Eds.), International and Development Education: Higher Education Regionalization in Asia Pacific: Implications for Governance, Citizenship and University Transformation. Gordonsville, VA: Palgrave Macmillan.

Knight, J. (2013). A model for the regionalization of higher education: The role and contribution of Tuning. Tuning Journal for Higher Education, 1(1), 105-125.

Lumina Foundation (2014). The Degree Qualifications Profile: A learning-centered framework for what college graduates should know and be able to do to earn the associate, bachelor's or master's degree. Indianapolis, IN: Author.

McInerney, D. (2017). Tuning the Discipline of History in the United States: Harmony (and dissonance) in teaching and learning. Arts \& Humanities in Higher Education, 16(4), 337-357.

Oanda, I. O. (2013). Trends in internationalization of higher education and implications for research and innovation for development in African universities. In A. W. Wiseman \& C. C. Wolhuter (Eds.), The Development of higher education in Africa: Prospects and challenges (pp.69-97). Bingley, UK: Emerald Publishing.

Trow, M. (2000). From mass higher education to universal education: The American advantage. Minerva 37, 1-26.

Van der Wende, M. (2009). European responses to global competitiveness in higher education. In J.A. Douglass, C. J. King \& I. Feller (Eds.), Globalization's muse: universities and higher education systems in a changing world (pp. 317-341). Berkley, CA: Public Policy Press/Center for Studies in Higher Education.

van der Wende, M.C. (2000). The Bologna Declaration: Enhancing the transparency and competitiveness of European higher education. Journal of Studies in International Education 4 (2): 3-10. 
Woldegiyorgis, A. A. (2018). Harmonization of higher education in Africa and Europe: Policy convergence at supranational level. Tuning Journal for Higher Education, 2(5), 133157. 